Original Research Article

\title{
Cost variation among antiretroviral drugs: pharamcoeconomical prospective
}

\author{
Dinesh Jiwane, Arun Kumar Srivastav, Neelesh Arya*, Mithlesh Mehar
}

Department of Pharmacology, Gandhi Medical College, Bhopal, Madhya Pradesh, India

Received: 22 February 2018

Accepted: 28 February 2018

\section{*Correspondence to:}

Dr. Neelesh Arya,

Email: drneelesharya@ gmail.com

Copyright: (c) the author(s), publisher and licensee Medip Academy. This is an openaccess article distributed under the terms of the Creative Commons Attribution NonCommercial License, which permits unrestricted noncommercial use, distribution, and reproduction in any medium, provided the original work is properly cited.

\begin{abstract}
Background: Acquired immunodeficiency syndrome (AIDS) is a disorder caused by the human immunodeficiency virus (HIV). Main characteristic feature of AIDS includes severe immunosuppression which leads to opportunistic infections which is a main cause of death and requires a lifelong therapy. There exists wide range of cost variation in antiretroviral drugs that are marketed in India. The current study aims to view the existing situation of antiretroviral drugs, by collecting data about the cost of common antiretroviral drugs available either singly or in combination and to evaluate the difference in cost of different brands of same active drug by calculating percentage cost variation.

Methods: Data for calculating cost ratio and percentage price variation of various antiretroviral drugs was obtained from "Current Index of Medical Specialties" October 2017-January2018.

Results: Zidovudine $100 \mathrm{mg}$ shows maximum cost ratio and price variation followed by Lamivudin 100mg in the single drug therapy. Lamivudine $150 \mathrm{mg}+$ Zidovudine $300 \mathrm{mg}$ shows maximum price variation in combination drug therapy. Conclusions: Indian market shows wide price variation of different brands of the same generic antiretroviral drug. To decrease the wide cost variation among different brands of antiretroviral drugs; it is time to create awareness among healthcare professionals about impact of cost effectiveness of drug regimen and decrease the financial burden on the patients.
\end{abstract}

Keywords: Antiretroviral drugs, Drug price control order, Percentage cost variation, Pharmaceutical industry

\section{INTRODUCTION}

Acquired immunodeficiency syndrome (AIDS) is a disorder caused by the human immunodeficiency virus (HIV). Main characteristic feature of AIDS is severe immunosuppression that leads to opportunistic infections, neurologic complications and secondary neoplasms. ${ }^{1}$ According to WHO 2016 report, currently there are 36.7 million people affected by AIDS worldwide. ${ }^{2}$ India has the third highest number of estimated people living with HIV in the world. According to the HIV estimations 2016, the estimated number of people living with HIV/AIDS in India was 2.1 million, with an estimated adult (15-49 age group) HIV prevalence of $0.3 \%$ in $2016 .^{3}$

For the treatment of chronic disorder like HIV, high cost of medicines is a burden on the patient. One of the important reasons for the noncompliance by the patient is high cost of medicines, thus leading to increase in the morbidity associated with the HIV. Hence, cost of therapy should be an important consideration in selecting the antiretroviral therapy. There is a wide variation in prices of the antiretroviral drugs and prescribing a cheaper brand will be an economically viable option to the patient, leading to increased adherence to therapy in the long-term treatment of HIV. Taking bio-equivalence data into 
consideration, generic drugs are widely believed to be as bio-equivalent and have same therapeutic effects as the innovator products. ${ }^{4}$

Indian pharmaceuticals market stands third largest in terms of value and thirteenth largest in terms of volume in the Global Pharmaceutical Industry. India is the largest provider of generic drugs in terms of volume. It is expected that Indian pharmaceutical market will emerge as the sixth largest market at the global level on the basis of absolute size by 2020 . Indian pharmaceutical market has the domination of the branded generics. In terms of revenue, around $80 \%$ of the market share is occupied by branded generics. $^{5}$

The Indian health sector has been affected by increasing cost of production of pharmaceutical company, economic policies, and structural adjustment reforms by the World Bank. Increasing price of medicines can be a reason for people not accessing health care. ${ }^{6}$

Indian markets have a large number of branded formulations for antiretroviral medications with variation in pricing difference, between the different brands of the same formulation. This leads to unfair burden on the patients. ${ }^{7}$

In India, majority of the health care costs are afforded by patients. India has highest Out of Pocket (OOP) expenses on health care. India is one of the largest manufacturers of generic drugs while about $65 \%$ of Indians do not have access to essential medicines. ${ }^{8}$

The current study aims to view the existing situation of antiretroviral drugs, by collecting data about the cost of common antiretroviral drugs available either singly or in combination and to evaluate the difference in cost of different brands of same active drug by calculating percentage cost variation.

\section{METHODS}

Antiretroviral drug manufactured by different pharmaceutical companies in different formulation were analyzed for the cost variation. Data of a particular brand (cost per 10 tablets) of antiretroviral drugs were collected from "Current Index of Medical Specialties" (CIMS) October 2017 - January 2018.

\section{Inclusion criteria}

- Antiretroviral drugs which are available as single preparation or in combination.

- Antiretroviral drugs manufactured by more than one pharmaceutical company.

- Antiretroviral drugs with complete verifiable information regarding strengths, formulations, brand name and cost.

\section{Exclusion criteria}

- $\quad$ The drugs being manufactured by only one company.

- Antiretroviral drugs with incomplete or nonverifiable information regarding strengths, formulations, brand name or cost.

Calculation for cost ratio was done by dividing the maximum to minimum cost of the various brands of the same drug. Percentage cost variation was calculated by following formula: ${ }^{9}$

$$
\text { Cost variation }(\%)=\underline{\text { Max. } \cos t-\operatorname{Min} \cdot \operatorname{Cost} \times 100}
$$

Min. cost

\section{RESULTS}

The prices of 15 antiretroviral drugs ( 9 single and 6 combinations) available in different formulations were analysed.

Table 1 shows variation in cost of antiretroviral drugs used as a single drug therapy. Highest cost ratio (1: 8.49) and percentage cost variation (749.21) was found for zidovudine $(100 \mathrm{mg})$, followed by lamivudine $(100 \mathrm{mg})$ [ $(1$ : 4.61) and 360.53] and didanosine 250mg [(1: 1.74) and 73.61].

Table 1: Variation in cost of single drug therapy.

\begin{tabular}{|llllll|}
\hline \multirow{2}{*}{ Drug } & Strength & $\begin{array}{l}\text { Max. } \\
\text { cost } \\
\text { (INR) }\end{array}$ & $\begin{array}{l}\text { Min. } \\
\text { cost } \\
\text { (INR) }\end{array}$ & $\begin{array}{l}\text { Cost } \\
\text { ratio }\end{array}$ & $\begin{array}{l}\text { \% cost } \\
\text { variation }\end{array}$ \\
\hline \multirow{2}{*}{ Zidovudine } & $300 \mathrm{mg}$ & 160 & 131 & 1.22 & $22.14 \%$ \\
\cline { 2 - 6 } & $100 \mathrm{mg}$ & 535 & 63 & 8.49 & $749.21 \%$ \\
\hline \multirow{2}{*}{ Lamivudin } & $10 \mathrm{mg}$ & 350 & 76 & 4.61 & $360.53 \%$ \\
\cline { 2 - 6 } & $150 \mathrm{mg}$ & 117 & 85 & 1.38 & $37.65 \%$ \\
\hline \multirow{2}{*}{ Stavudine } & $30 \mathrm{mg}$ & 38 & 28 & 1.36 & $35.71 \%$ \\
\cline { 2 - 6 } & $40 \mathrm{mg}$ & 43 & 32 & 1.34 & $34.38 \%$ \\
\hline \multirow{2}{*}{ Efavirenz } & $600 \mathrm{mg}$ & 774 & 666.67 & 1.16 & $16.10 \%$ \\
\cline { 2 - 6 } & $200 \mathrm{mg}$ & 289 & 243.33 & 1.19 & $18.77 \%$ \\
\hline \multirow{2}{*}{ Didanosine } & $400 \mathrm{mg}$ & 650 & 390 & 1.67 & $66.67 \%$ \\
\cline { 2 - 6 } & $250 \mathrm{mg}$ & 416.7 & 240 & 1.74 & $73.61 \%$ \\
\hline Indinavir & $400 \mathrm{mg}$ & 200 & 180 & 1.11 & $11.11 \%$ \\
\hline Abacavir & $300 \mathrm{mg}$ & 500 & 470 & 1.06 & $6.38 \%$ \\
\hline Nelfinavir & $250 \mathrm{mg}$ & 256.8 & 240 & 1.07 & $7.00 \%$ \\
\hline Ritonavir & $100 \mathrm{mg}$ & 300 & 275 & 1.09 & $9.09 \%$ \\
\hline
\end{tabular}

Table 2 shows variation in the cost of antiretroviral drugs used in combinations. Highest cost ratio (1: 3.98) and percentage cost variation (298.06) was found for Lamivudine (150mg) + zidovudine (300mg).

\section{DISCUSSION}

In this study, it was found that there exists large variation among antiretroviral drugs with maximum variation in zidovudine and minimum with abacavir. 
It is observed from our results that there is a wide (up to $749 \%$ ) variation in cost of drugs manufactured by different pharmaceutical companies. The reasons for this price variation could be as follows: ${ }^{10-16}$

1. Increasing competition between pharmaceutical companies
2. Advertising costs

3. lack of information

4. Government regulations and pricing policies.

5. Present marketing structure of the pharmaceutical industry

Table 2: Variation in cost of combination drug therapy.

\begin{tabular}{|llllll|}
\hline \multirow{2}{*}{ Drug } & Strength (mg) & $\begin{array}{l}\text { Max. cost } \\
\text { (INR) }\end{array}$ & $\begin{array}{l}\text { Min. cost } \\
\text { (INR) }\end{array}$ & $\begin{array}{l}\text { Cost ratio } \\
\text { Lamivudine +Stavudine }\end{array}$ & $\begin{array}{l}\text { cost } \\
\text { variation }\end{array}$ \\
\hline \multirow{2}{*}{ Lamivudine +Stavudine + Nevirapine } & $150+30$ & 116 & 115 & 1.01 & $0.87 \%$ \\
& $30+6+50$ & 90 & 115 & 1.09 & $8.70 \%$ \\
\cline { 2 - 6 } & $60+12+100$ & 126.67 & 125 & 1.01 & $31.07 \%$ \\
\hline Tenofovir + Emicitrabine + Efavirenz & $150+30+200$ & 220 & 181.33 & 1.21 & $21.32 \%$ \\
\hline Lamivudine + Zidovudine & $150+300$ & 820 & 206 & 3.98 & $298.06 \%$ \\
\hline Lamivudine + Zidovudine + Nevirapine & $150+300+200$ & 238.67 & 200 & 1.19 & $19.33 \%$ \\
\hline Tenofovir + Emicitrabine & $300+200$ & 666.67 & 466.67 & 1.43 & $42.86 \%$ \\
\hline
\end{tabular}

In India, patients have to pay for the drugs from their pockets because most of the people are not covered under medical insurance. Therefore, patients belonging to lower socio-economic strata cannot afford it. This nonaffordability of medicines leads to poor compliance. It has been observed that healthcare professionals do not take into consideration the economic status of the patient before prescribing.

It is difficult for doctors to prescribe the most economical prescription as there is absence of information on comparative drug prices and quality. ${ }^{17}$

Government issue an order called Drug price control order (DPCO), to fix the prices of drugs. Once the drug is brought under the purview of DPCO, it cannot be sold at a price higher than the price fixed by the government. In $1979,80-85 \%$ of the drugs in the market were under price control in India. The number has slowly declined and by 2002 , only $15-20 \%$ drugs were under price control. ${ }^{18}$ Therefore, the common man, has to shell out more money on drug prices, which ultimately crawl out of his reach.

Presently, only a few drugs are under DPCO price control, more number of essential drugs needs to be brought under DPCO so that economic implications of cost variation could be prevented.

It seems that there is lack of appreciation among the healthcare professionals for the price variation between the inexpensive and expensive drugs. ${ }^{9}$ This can be due to the fact that pharmacoeconomical aspect of a treatment regimen are often neglected during their undergraduate and postgraduate study period. It has also been observed that physicians often overestimate the cost of inexpensive drugs and underestimate the cost of expensive drugs. This can result in increased overall healthcare costs. ${ }^{19}$

This unawareness of the treating physician regarding cost variation of various brands of the same drug can be minimized by providing manual having information regarding comparative drug costs along with prescribing advices. ${ }^{20}$

Recently, Medical council of India has issued a circular which state that drugs should be prescribed only by their generic names. ${ }^{21}$ This regulation ensures the prevention of any specific brand of a drug but it does not specify the role of pharmacist who dispenses the brand. The regulation should also specify the pharmacist to decrease the treatment costs by dispensing the brand with lesser cost.

It has been observed that price variations of different brands of same drug are linked to marketing strategyy of that particular brand. That brand who make aggressive marketing promotion have higher costs as compared to the brands with no marketing promotion. There has been no correlation found between the cost and the quality of the particular brand of drug. ${ }^{22}$

\section{CONCLUSION}

There exists wide price variation of different brands of the same generic antiretroviral drug in Indian market. Drug cost plays an important role in treatment of HIV as it follows a long course. To decrease the wide cost variation among different brands of antiretroviral drugs; it is time to create awareness about impact of cost effectiveness of 
drug regimen and reduce the economic burden on the patients.

Funding: No funding sources

Conflict of interest: None declared

Ethical approval: Not required

\section{REFERENCES}

1. Longo DL, Fauci AS, Kasper DL, Hauser SL, Jameson J, Loscalzo J. eds. Harrison's Principles of Internal Medicine, $19^{\text {th }}$ Ed. New York, NY: McGraw-Hill; 2015.

2. World Health Organization [Online]. 2016 [cited 2018 Feb 7]; Available at: URL:http://www.who.int/gho/hiv/en/

3. National AIDS Control Organization [Online]. 2016 [cited 2018 Feb 10]; Available at: URL:http://naco.gov.in/sites/default/files/NACO $\% 20$ ANNUAL\%20REPORT\%202016-17.pdf

4. Patel D, Thiyagu R, Surulivelrajan M, Patel H, Pandey S. Price variability among the oral antibiotics available in a South Indian Tertiary Care Hospital. J Clin Diagn Res. 2009;3(6):1871-5.

5. Indian Pharmaceutical Industry [Online]. 2018 [cited 2018 Feb 8]; Available at: https://www.ibef.org/industry/pharmaceutical-india.

6. Shankar PR, Subish P, Bhandari RB, Mishra P, Saha AC. Ambiguous pricing of topical dermatological products: a survey of brands from two South Asian countries. J Pak Assoc Dermatol. 2006;16:134-40.

7. Das SC, Mandal M, Mandal SC. A critical study on availability and price variation between different brands: Impact on access to medicines. Indian J Pharm Sci. 2007;69(1):160-3.

8. Operational Guidelines on Free drug service Initiative. National Health Mission. [Online]. 2012 [cited 2018 Feb 4]; Available at: http://nhm.gov.in/images/pdf/NHM/NHMGuidelines/Free_Drugs_Service_Intitiative.pdf

9. Akila L, Rani RJ. Cost analysis of different brands of antianginal drugs available in India. Int J Basic Clin Pharmacol. 2015;4:860-3.

10. Sarkar PK. A rational drug policy. Indian J Med Ethics. 2004;12:30-5.

11. Roy V, Rewari S. Ambiguous drug pricing: a physician's dilemma. Indian J Pharmacol. 1998;30:404-7.
12. Wertheimer AI, Grumer SK. Overview of international pharmacy pricing. Pharmacoeconomics. 1992;2(6):449-55.

13. Berki SE, Richards JW, Weeks HA. The mysteries of prescription pricing in retail pharmacies. Med Care. 1977;15(3):241-50.

14. Rataboli PV, Dang A. Antimicrobial price variation: conundrum of medical profession! J Postgrad Med. 2007;53(1):72-4.

15. Das SC, Mandal M, Mandal SC. A critical study on availability and price variation between differ rent brands: impact on access to medicines. Indian J Pharm Sci. 2007;69(1):160-3.

16. Dawadi S, Rao BS, Khan GM. Pattern of antimicrobial prescription and its cost analysis in respiratory tract infection. Kathmandu Univ J Sci Eng Technol. 2005;1(1):1-9.

17. Frazier LM, Brown JT, Divine GW, Fleming GR, Philips NM, Siegal WC, et al. Can physician education lower the cost of prescription drugs? A prospective, controlled trial. Ann Intern Med. 1991;115(2):116-21.

18. Jana S, Mondal P. Pharmacoeconomics: the need to sensitize undergraduate medical students. Indian $\mathbf{J}$ Pharmacol. 2005;37(5):277-8.

19. Allan GM, Lexchin J, Wiebe N. Physician awareness of drug cost: A systematic review. PLoS Med. 2007;4(9):e283.

20. Frazier LM, Brown JT, Divine GW, Fleming GR, Philips NM, Siegal WC, et al. Can physician education lower the cost of prescription drugs? A prospective, controlled trial. Ann Intern Med. 1991;115(2):116-21.

21. Medical Council of India [Online]. 2016 [cited 2018 Feb 10]; Available at: http://www.ipgmer.gov.in/PharmacovigilanceCommi ttee/MCI_CircularUseofGenericNames20170421.pdf

22. Singal GL, Nanda A, Kotwani A. A comparative evaluation of price and quality of some branded versus branded-generic medicines of the same manufacturer in India. Indian J Pharmacol. 2011;43:131-6.

Cite this article as: Jiwane D, Srivastav AK, Arya $\mathrm{N}$, Mehar M. Cost variation among antiretroviral drugs: pharamcoeconomical prospective. Int J Basic Clin Pharmacol 2018;7:594-7. 